\title{
Effectiveness of Flipped Learning Instructional Pedagogy on Academic Achievement in Chemistry
}

\author{
Vandana $\mathbf{M}^{1}$, Dr. Haseen Taj ${ }^{2}$ \\ ${ }^{1}$ Research Scholar, Department of Education, Bangalore University, Bangalore 560056 \\ ${ }^{2}$ Chairperson and Dean, Department of Education, Bangalore University, Bangalore 560056
}

\begin{abstract}
Chemistry is a branch of Science and very much necessary to study at School level. It helps Students to understand the world around them and develop scientific attitude and skill. Modern digital pedagogies strive to instil interest in learning Chemistry among students and develop self-directed learning skills. Flipped learning is one such digital pedagogy which engages students in learning process and in their academic achievement. It provides suitable activities to develop Lower Order Thinking Skills and Higher Order Thinking Skills effectively among students. In this experimental study the Researcher attempted to explore the effectiveness of Flipped Learning Instructional Pedagogy in comparison with Traditional learning method on Academic Achievement in Chemistry of Secondary School Students. The analysis of the data collected shows that there is significant difference in mean scores of Academic Achievement in Chemistry of students who were taught using FLIP and Traditional learning method, further there is increase in Academic Achievement of students who were taught using FLIP and increase in learning progress as compared to their counterparts. FLIP provides opportunities for teachers to engage their students more actively and involve them in practical work to create interest in learning Chemistry and increase the Academic Achievement.
\end{abstract}

Key Words: Flipped Learning, Academic Achievement, Lower Order Thinking Skills, Higher Order Thinking Skills.

\section{INTRODUCTION:}

Chemistry a branch of Science that deals with the study of structure, composition and properties of matter. It is very important to study Chemistry at school Curriculum as everything surrounds us is chemical entities. It plays very important role in learning natural sciences. In day-to-day life whatever we use from morning till night is made up of chemicals. Chemicals are not only in the medicine which we consume when we are sick, it is also present in the food we eat, water or any beverages we drink, air we breathe and every things we use daily and regularly are made up to of chemicals. Therefore, learning chemistry is very essential for children at school level itself. It helps students to understand the world around them, to keep them safe, to develop scientific attitude, develop observation skills, and draw inferences after experimentation. Knowledge of chemistry is very essential for students who wish to enter courses like medical, engineering or in the field of Food and Hotel management, fashion designing, dyes and paints, textile industry etc. Study of science is compulsory at secondary level to develop scientific attitude, observation skills, inquiry, questioning among students. According to NCF-2005, major objective of teaching Chemistry at school level is to engage learners in learning activities, experiments, nurture creativity, incorporate diverse learning activities. Thus, it recommends inclusion of innovative pedagogies in teaching-learning process. Now there is a pedagogical shift from teacher centered classrooms to learner centered classrooms. The role of teacher is changed to a facilitator, a Guide by the side, and to design instructional activities to engage learners creatively to construct their knowledge and involve every student in the learning process. Teacher is not just a knowledge provider but catalyst to ignite love of knowledge among the students.

Though chemistry is practical oriented subject digital methods of teaching-learning also have scope in teaching chemistry. Digital methods of teaching motivate students to develop self-directed learning skills. They arouse interest and engage students in learning. Digital tools and technologies enable teachers to share the information with their students in real time. It helps to fill the gaps in traditional learning pedagogy and inspires creativity among students. Many abstract concepts in Chemistry can be simplified by using suitable ICT tools. Simulations and animations helps in better understanding of concepts which cannot be demonstrated or experimented in regular classrooms or laboratories. Digital technologies helps to create and use animations and simulations which gives first-hand experience to students. Modern pedagogies make use of these digital technology in teaching-learning. They do not replace teacher and teaching-learning inside classroom instead gives support for learning process which happens inside the classroom to enhance students learning and becomes a tool in the hands of teacher to nurture the creativity of their students. Reverse instruction or 


\title{
International Advanced Research Journal in Science, Engineering and Technology
}

\author{
Vol. 8, Issue 8, August 2021
}

\section{DOI: 10.17148/IARJSET.2021.8840}

Inverse teaching or Flipped learning is one such innovative pedagogy which enhances students' academic achievement in chemistry.

\section{RATIONALE OF THE STUDY}

Flipped learning is reversal of teaching -learning process to increase students' involvement in learning process, help students to construct and retain their knowledge, develop cooperative and collaborative skills, develop higher order thinking among students. The Flipped Learning Network (2014) defines flipped learning as moving direct instruction 'from the group learning space to the individual learning space' where the 'resulting group space is transformed'. Flipped classrooms are envisioned for more in-depth and collaborative learner-content interaction, knowledge construction can be an important learning outcome. Flipped instruction has three stages namely, Pre-class, In-class and Post-class (Estes, 2013).

Pre-class: It is the first stage which takes place before the class session at the pace, place and time of learner. Learner is provided with pre-learning resources and pre-learning activities designed to develop lower order thinking skills to complete before coming to the class. Instructor will move face-to-face classroom time to an asynchronous environment. Instructors may design creative, pre-recorded materials in a variety of media formats (Mazur, 2009; Demski, 2013). In the asynchronous environment instructors assess student learning and comprehension and use resulting data to effectively design the next in-class session.

In-class: It is the second stage which happens in real time during the face to face class session. In this stage, Instructor prompts to increase student-teacher contact through in-class discussion, observation, and possibly the use of technologies such as learner response systems. Students mostly work in groups and engage in activities that are designed to develop higher order thinking skills. Teacher is a facilitator and encourages all students to participate in activities and interacts with students for learning outcomes. It is common to use peer feedback and peer teaching for discovery and practice (Crouch, Watkins, Fagen, \& Mazur, 2007; Powell, 2003). Increasing instructor-student and student-student contact is the best practice in higher education (Chickering \& Gamson, 1987).

Post-class: It is the final and third stage which occurs out of class session at the pace and place of learner. When the asynchronous and synchronous components of flipping have happened, instructors have an opportunity to increase and endure student motivation for engagement outside of class time, and to assess learner progress. The instructor may incorporate extrinsic motivators such as associating out-of-classroom learning tasks with grades and setting clear expectations for in-class engagement. Learners are engaged even after the class session to engage them cognitively and increase their higher order thinking skills by providing both individual and group assignments out of the class.

Flipped learning allows students to develop deep learning and self-learning skills outside the classroom at their pace. It also enable students to work collaborately in groups during in-class time to engage them creatively to increase their academic achievement.

Pre- learning materials provided to students allows the students to go through the resources at their pace, to re-wind as per requirements to understand the basic concepts before class session (Glynn, 2013), helps the students to prepare for the activities during synchronous session. In-class session engages every student, teacher conducts both group and individual learning activities. Performance of students increases as a result of these activities conducted during in-class (Carlson \& Winquist, 2011) and increase student - student and student - teacher interactions, every student gets the teacher guidance during small group activities conducted during in-class (Snowden, 2012), students will be actively engaged during class time, get optimum time to clarify the concept and interact with peers and teacher. Flipped learning increases student motivation and student engagement, increases active involvement and self-determination of students (Calderara \& Wiebe, 2019), enhances the retention of the knowledge and thus Students' academic achievement increases with better performance (Alastuey \& Galar, 2017).

As evidenced from above, Flipped learning is an innovative Instructional pedagogy which engages students in learning before, during and after the class sessions, involves every learner actively in the learning process and increases their Academic Achievement. It provides scope to cater for both lower order thinking skills and higher order thinking skills effectively and develops deep learning skills, enhance collaborative skills and provides concrete examples for abstract concepts which students learn at their pace and time. Therefore, the researcher attempted to investigate the Effectiveness of Flipped Learning Instructional Pedagogy on Academic Achievement in Chemistry for students of Class 9 in this experimental study.

\section{Objectives:}

1. To compare the effect of Flipped Learning Instructional Pedagogy with Traditional Learning on Academic Achievement in Chemistry of students.

2. To find out the difference in Academic Achievement in Chemistry of Students who were taught using Flipped Learning Instructional Pedagogy and Traditional Learning Pedagogy.

3. To find out the difference in Progressive tests in Chemistry of Students who were taught using Flipped Learning Instructional Pedagogy and Traditional Learning Pedagogy. 


\section{DOI: 10.17148/IARJSET.2021.8840}

4. To investigate the Main and Interaction effect of Teaching Method with Sex on Academic Achievement of Students from Control and Experimental groups

5. To investigate the Main and Interaction effect of Teaching Method with Levels of Socio Economic Status on Academic Achievement of Students from Control and Experimental groups

\section{HYPOTHESES OF THE STUDY}

1. There is no significant difference between the Control group and Experimental group's Pre-test scores of Academic Achievement in Chemistry.

2. There is no significant difference between the Control group and Experimental group's Post-test scores of Academic Achievement in Chemistry.

3. There is no significant difference between the pre-test and post-test mean scores of Academic Achievement in Chemistry of Experimental group of students.

4. There is no significant difference between the pre-test and post-test mean scores of Academic Achievement in Chemistry of Control group of students.

5. There is no significant difference between the Experimental group and Control group's mean scores of Progressive test 1 in Chemistry.

6. There is no significant difference between the Experimental group and Control group's mean scores of Progressive test 2 in Chemistry.

7. There is no significant Main and Interaction effect of Teaching Methods and Sex with each other on Academic Achievement in Chemistry.

8. There is no significant Main and Interaction effect of Teaching Methods and Socio Economic Status with each other on Academic Achievement in Chemistry.

\section{METHODOLOGY}

The present experimental study was conducted for $9^{\text {th }}$ standard students in a Private Secondary School located in Bangalore city utilizing randomised matching pre-test post-test equivalent group design. 48 students were identified by the researcher for having digital device access to complete their digital assignments required for the present study after School hours. All students were administered with Ravens Progressive Matrices and Socio Economic Scale (Developed by Prof. Haseen Taj, 2012) to equalize the groups, later students were randomly divided into two groups and equated on Intelligence, Socio-economic status and previous achievement test in science (considered from school records) as t-test resulted not significant. Students were randomly assigned to experimental and control groups with 24 students in each group. Later a Pre-test on Academic Achievement in Chemistry was administered to both Experimental and Control groups using the tool developed by Vandana M \& Prof. Haseen Taj (2019).

Experimental group of students were taught a unit from Chemistry part of Science for Class 9 using Flipped learning Instructional pedagogy and the same lesson was taught to control group of students using traditional method of teaching. FLIP package on the unit taught was prepared by the Researcher. This unit was divided into 8 modules and Sub-modules in each modules. Researcher prepared pre-recorded videos, slides, animations, images, text files on each sub modules of the lesson to be taught and also pooled open educational resource e-content on the same topic of lesson, and was made available to experimental group of students in LMS MOODLE.

Experimental group of students were trained to access the MOODLE to complete their pre-class activities which included watching the pre-recorded videos of the lesson, reading various formats of e-content provided and completion of these pre-learning activities in the MOODLE catered to lower order thinking skills before attending face-to-face in-class session. Laboratory work, Quiz, Small group activities and individual activities using active learning strategies by providing worksheets were conducted during the in-class session to develop higher order thinking skills among students. Student-student and student-teacher interaction was seen maximum during the in-class session. Post-class activities like H5P, Moodle Quiz on each module and forums to discuss on the reasoning questions were made available in MOODLE after every in-class session to sustain student attention and motivation outside the class.

Traditional Method of teaching using lecture and demonstration method was used teach the same lesson for Control group of students. Questions were asked to students during the class to check the understanding, and displayed few Charts to explain the concepts. Both Experimental and Control group of students were taught in Flipped learning instruction and Traditional learning respectively for 7 weeks and a Post-test on Academic Achievement in Chemistry was administered to both Experimental and Control group of students.

\section{FINDINGS}

The data on pre-test and post-test scores on Academic Achievement in Chemistry, Progressive tests 1 and 2 in Chemistry were analysed using t-test and 2 Way ANOVA. Findings of the analysis were tabulated as below. 
International Advanced Research Journal in Science, Engineering and Technology

Vol. 8, Issue 8, August 2021

DOI: 10.17148/IARJSET.2021.8840

Table 1: Showing t-test analysis for equating Experimental and Control group students

\begin{tabular}{|c|c|c|c|c|c|}
\hline Groups & $\mathbf{N}$ & Mean & SD & $\begin{array}{c}c t \\
\text { value }\end{array}$ & $\begin{array}{c}\text { Level of } \\
\text { Significan } \\
\text { ce }\end{array}$ \\
\hline \multicolumn{6}{|c|}{ Ravens Progressive Matrices } \\
\hline Experimental & 24 & 44.54 & 6.840 & \multirow{2}{*}{0.927} & \multirow{2}{*}{ NS } \\
\hline Control & 24 & 42.71 & 6.862 & & \\
\hline \multicolumn{6}{|c|}{ Socio Economic Status } \\
\hline $\begin{array}{l}\text { Experimental } \\
\text { Group }\end{array}$ & 24 & 99.96 & 9.234 & \multirow[t]{2}{*}{0.226} & \multirow[t]{2}{*}{ NS } \\
\hline Control Group & 24 & 100.5 & 7.283 & & \\
\hline \multicolumn{6}{|c|}{ Previous Science Achievement } \\
\hline $\begin{array}{l}\text { Experimental } \\
\text { Group }\end{array}$ & 24 & 70.58 & 6.487 & \multirow[t]{2}{*}{1.087} & \multirow[t]{2}{*}{ NS } \\
\hline Control Group & 24 & 68.50 & 6.789 & & \\
\hline
\end{tabular}

Table 2: Showing Pre-test scores of Academic Achievement in Chemistry between Experimental and Control

\begin{tabular}{|l|c|c|c|l|c|}
\hline Groups & N & Mean & SD & $\begin{array}{l}\text { t } \\
\text { value }\end{array}$ & $\begin{array}{c}\text { Level of } \\
\text { Significance }\end{array}$ \\
\hline Experimental & 24 & 8.92 & 2.466 & \multirow{2}{*}{1.095} & NS \\
\hline Control & 24 & 8.08 & 2.796 & & NS = Not Significant \\
\hline
\end{tabular}

Table 3: Showing Post-test scores of Academic Achievement in Chemistry between Experimental and Control group

\begin{tabular}{|l|l|l|l|l|c|}
\hline Groups & N & Mean & SD & $\begin{array}{l}\text { t } \\
\text { value }\end{array}$ & $\begin{array}{c}\text { Level of } \\
\text { Significance }\end{array}$ \\
\cline { 1 - 5 } Experimental & 24 & 28.21 & 4.22 & \multirow{2}{*}{3.458} & $* *$ \\
\hline Control & 24 & 23.33 & 5.467 & & \\
\hline
\end{tabular}

Table 4: Showing Pre-test and Post-test scores of Academic Achievement in Chemistry of Experimental and Control group's

\begin{tabular}{|c|c|c|c|c|c|}
\hline Groups & $\mathbf{N}$ & Mean & SD & t value & $\begin{array}{c}\text { Level of } \\
\text { Significa } \\
\text { nce }\end{array}$ \\
\hline \multicolumn{6}{|c|}{ Experimental Group } \\
\hline Pre-test & 24 & 8.92 & 2.466 & \multirow{2}{*}{22.807} & \multirow{2}{*}{$* *$} \\
\hline Post-test & 24 & 28.21 & 4.22 & & \\
\hline \multicolumn{6}{|c|}{ Control Group } \\
\hline Pre-test & 24 & 8.08 & 2.796 & \multirow{2}{*}{18.131} & \multirow{2}{*}{$* *$} \\
\hline Post-test & 24 & 23.33 & 5.467 & & \\
\hline
\end{tabular}

Table 5: Showing Progressive tests 1 and 2 in Chemistry scores of Experimental and Control groups

\begin{tabular}{|l|c|c|c|c|c|}
\hline Groups & N & Mean & SD & $\begin{array}{c}\text { t } \\
\text { value }\end{array}$ & $\begin{array}{c}\text { Level of } \\
\text { Significance }\end{array}$ \\
\hline Progressive Test 1 in Chemistry \\
\hline Experimental & 24 & 20.83 & 1.685 & 5.369 & $* *$ \\
\hline Control & 24 & 16.00 & 4.075 & & \\
\hline Progressive Test 2 in Chemistry \\
\hline Experimental & 24 & 21.21 & 1.474 & \multirow{2}{*}{6.920} & $* *$ \\
\hline Control & 24 & 15.12 & 4.047 & \\
\hline
\end{tabular}

The data on post-test scores of Academic Achievement in Chemistry of students of Experimental and control group was analysed using 2 way ANOVA and findings were tabulated as shown below.

(c) IARJSET This work is licensed under a Creative Commons Attribution 4.0 International License 
International Advanced Research Journal in Science, Engineering and Technology

Vol. 8, Issue 8, August 2021

DOI: 10.17148/IARJSET.2021.8840

Table 6: Showing Observed data for 2 Way ANOVA of Teaching method (Traditional Learning and Flipped Learning) of Boys and Girls of both Groups.

\begin{tabular}{|c|c|c|c|}
\hline \multicolumn{2}{|c|}{ Teaching Method } & $\begin{array}{l}\text { Traditional } \\
\text { Learning }\end{array}$ & $\begin{array}{l}\text { Flipped } \\
\text { Learning }\end{array}$ \\
\hline \multicolumn{4}{|l|}{ Sex } \\
\hline \multirow{3}{*}{ Boys } & $\mathrm{N}$ & 12 & 12 \\
\hline & Mean & 22.17 & 28.0 \\
\hline & SD & 6.576 & 4.178 \\
\hline \multirow{3}{*}{ Girls } & $\mathrm{N}$ & 12 & 12 \\
\hline & Mean & 24.50 & 28.42 \\
\hline & SD & 4.034 & 4.441 \\
\hline
\end{tabular}

Table 7: Results of 2 way ANOVA for post-test scores of Academic Achievement in Chemistry with Independent variables namely, Sex and Teaching method.

\begin{tabular}{|l|c|c|c|c|c|}
\hline $\begin{array}{l}\text { Source of } \\
\text { Variation }\end{array}$ & $\begin{array}{c}\text { Sum of } \\
\text { Squares }\end{array}$ & Df & $\begin{array}{c}\text { Mean } \\
\text { Squares }\end{array}$ & $\begin{array}{c}\text { F - } \\
\text { Value }\end{array}$ & $\begin{array}{c}\text { Level of } \\
\text { Significance }\end{array}$ \\
\hline Sex & 22.688 & 1 & 11.688 & 0.939 & NS \\
\hline $\begin{array}{l}\text { Teaching } \\
\text { Method }\end{array}$ & 285.187 & 1 & 185.187 & 11.798 & $* *$ \\
\hline $\begin{array}{l}\text { Sex X } \\
\text { Teaching } \\
\text { Method }\end{array}$ & 11.021 & 1 & 11.021 & 0.456 & NS \\
\hline Error & 1063.583 & 44 & 24.172 & & \\
\hline Total & 1382.479 & 47 & & & \\
\hline
\end{tabular}

Table 8: Showing Observed data for 2 Way ANOVA of Teaching method (Traditional Learning and Flipped Learning) of Low, Moderate and High levels of Socio Economic Status of both Groups.

\begin{tabular}{|l|l|c|c|}
\hline \multicolumn{2}{|l|}{ Teaching Method } & Traditional Learning & Flipped Learning \\
\hline \multirow{2}{*}{ Levels of SES } & $\mathrm{N}$ & 6 & 6 \\
\hline \multirow{4}{*}{ Low } & Mean & 23.83 & 28.0 \\
\cline { 2 - 4 } & SD & 4.834 & 5.099 \\
\hline \multirow{4}{*}{ Moderate } & $\mathrm{N}$ & 11 & 27.17 \\
\cline { 2 - 4 } & Mean & 23.73 & 4.569 \\
\cline { 2 - 4 } & SD & 6.214 & 6 \\
\hline \multirow{3}{*}{ High } & $\mathrm{N}$ & 7 & 30.50 \\
\cline { 2 - 4 } & Mean & 22.29 & 1.049 \\
\cline { 2 - 4 } & SD & 5.376 & . \\
\hline
\end{tabular}

Table 9: Results of 2 way ANOVA for Post-test scores of Academic Achievement in Chemistry with Independent variables namely, Levels of SES and Teaching method.

\begin{tabular}{|l|c|c|c|c|c|}
\hline \multicolumn{1}{|c|}{$\begin{array}{c}\text { Source of } \\
\text { Variation }\end{array}$} & $\begin{array}{c}\text { Sum of } \\
\text { Squares }\end{array}$ & Df & $\begin{array}{c}\text { Mean } \\
\text { Squares }\end{array}$ & $\begin{array}{c}\text { F - } \\
\text { Value }\end{array}$ & $\begin{array}{c}\text { Level of } \\
\text { Significa } \\
\text { nce }\end{array}$ \\
\hline $\begin{array}{l}\text { Levels of } \\
\text { SES }\end{array}$ & 7.547 & 2 & 3.774 & 0.152 & NS \\
\hline $\begin{array}{l}\text { Teaching } \\
\text { Method }\end{array}$ & 306.307 & 1 & 306.31 & 12.351 & $* *$ \\
\hline $\begin{array}{l}\text { Levels of } \\
\text { SES X } \\
\text { Teaching } \\
\text { Method }\end{array}$ & 49.344 & 2 & 24.672 & 0.995 & NS \\
\hline Error & 1041.61 & 42 & 24.800 & & \\
\hline Total & 1382.48 & 47 & & & \\
\hline
\end{tabular}


International Advanced Research Journal in Science, Engineering and Technology

\author{
Vol. 8, Issue 8, August 2021
}

\title{
DOI: $10.17148 /$ IARJSET.2021.8840
}

\section{DISCUSSION OF RESULTS}

Table 1 reveals that there is no significant difference between the control group and experimental group students in their mean scores of Raven's Progressive Matrices for Intelligence test, mean scores of Socio Economic Status, and mean scores of Previous Achievement in Science, as observed from the obtained t values of 0.927, 0.226 and 1.087 are less than the table value of 2.021 at 0.05 level. From this it can be inferred that both Experimental and Control group of Students do not differ in their Intelligence, Socio Economic Status and Previous Achievement in Science.

The obtained $t$ value of 1.095 in Table 2 is less than the table value 2.021 at 0.05 level, from this it can be inferred that, both Control and Experimental groups do not differ in their Pre-test scores of Academic Achievement in Chemistry, hence the hypothesis 1 is accepted.

The obtained t value of 3.458 in Table 3 is greater than the table value of 2.704 at 0.01 level, from this it can be inferred that there is significant difference in the control group and experimental group students in their Post-test scores of Academic Achievement in Chemistry, hence the hypothesis 2 is rejected. Further it is observed that the Mean of Posttest of Academic Achievement in chemistry scores of Experimental groups of students is more than that of control group of students. This result is in agreement with the findings of the research conducted by Vimala \& Muniandy (2018) and result showed there is increase in academic achievement of students in experimental group when compared to that of students in traditional group. Flipped learning increases academic performance of students and students learn in from different learning culture (Alamri, 2019) and increases their academic achievement.

From Table 4 the obtained t values of 22.807, 18.131 are greater than the table value of 2.797 at 0.01 level, hence, hypotheses 3 and 4 are rejected and it can be interred that there is significant difference between the pre-test and Posttest mean scores of Academic Achievement in Chemistry of experimental group students and there is significant difference between the pre-test and Post-test mean scores of Academic Achievement in Chemistry of Control group students. It is observed that the Post-test mean scores of Academic Achievement in Chemistry are more than that of Pretest mean scores of Academic Achievement in Chemistry. Also the obtained t value of 22.807 of experimental group is greater than the obtained $t$ value of 18.131 of Control group. This infers that the Flipped Learning Instructional Pedagogy increases Academic Achievement of students in comparison with Traditional learning method. Similar results were obtained from the research conducted by Özüdoğru, M., \& Aksu, M. (2020) that there was significant high scores in achievement test for experimental group of students, Flipped Learning Instructional Pedagogy improves students' academic performance and improves pre-test to post-test in academic achievement of experimental group of students (Bueno-Alastuey \& Galar, 2017).

From Table 5 the obtained t values of 5.369, 6.920 are greater than the table value of 2.704 at 0.01 level, hence, hypotheses 5 and 6 are rejected and it can be inferred that there is significant difference in the control group and experimental group students in their Progressive test 1 in Chemistry and Progressive test 2 in Chemistry respectively. This result is in agreement with the results of research conducted by Saad ALRowais, A. (2014) that Flipped learning improves Students' attitude towards learning and it supports cooperative learning which influences students' learning achievement and course satisfaction in science education (Li, Y. Bin, Zheng, W. Z., \& Yang, F. (2017). This is indicative that the Flipped learning instructional pedagogy increases the academic achievement of students and students are engaged in activities which enhances their learning (Kaur, Gurpreet 2018).

From table 7 it is observed that, Sex has no significant Main effect $(F=0.939, p>0.05)$ on Academic Achievement in Chemistry of Students, Teaching Method (Traditional Learning and Flipped Learning Instructional Pedagogy) has significant Main effect $(\mathrm{F}=11.798, \mathrm{p}<0.01)$ on Academic Achievement in Chemistry of Students and there is no significant interaction effect of Sex and Teaching Method $(F=0.456, p>0.05)$ on Academic Achievement in Chemistry of Students. The result reveals that Sex has no effect on Academic achievement and Flipped Learning Instructional Pedagogy increases Academic achievement in chemistry of students. Flipped learning motivates students and increases their concentration (Kurushkin, M., \& Mikhaylenko, M., 2016), the process of learning was interesting and motivates the students to think critically (Valdez et al 2015). Group work allows students to self-assemble their groups and work on learning activities (Houseknecht, J. B. 2014), thus Flipped Learning Instructional Pedagogy increases academic achievement of Students.

From table 9 it is observed that, Levels of Socio Economic Status has no significant Main effect $(F=0.152, p>0.05)$ on Academic Achievement in Chemistry of Students, Teaching Method (Traditional Learning and Flipped Learning Instructional Pedagogy) has significant Main effect $(\mathrm{F}=12.351, \mathrm{p}<0.01)$ on Academic Achievement in Chemistry of Students and there is no significant interaction effect of Levels of Socio Economic Status and Teaching Method $(\mathrm{F}=$ 0.995, p >0.05) on Academic Achievement in Chemistry of Students. The result reveals that Levels of Socio Economic Status has no effect on Academic achievement and Flipped Learning Instructional Pedagogy increases Academic achievement in chemistry of students. Flipped Learning Instructional Pedagogy allows development of laboratory practices in the normal class schedule (Santa Montoya, C. A., 2014) and employs cooperative learning process (Tosun, 2014). The face-to-face supportive interaction between student-student and student-teacher encourage them to share their ideas, knowledge and help to construct their knowledge effectively (Acar, B., \& Tarhan, L., 2008). This results in the increase in academic achievement scores of students who learn using Flipped learning Instructional Pedagogy. 


\title{
International Advanced Research Journal in Science, Engineering and Technology
}

\author{
Vol. 8, Issue 8, August 2021
}

\section{DOI: 10.17148/IARJSET.2021.8840 \\ EDUCATIONAL IMPLICATIONS}

Flipped learning makes learning process more interesting and learning games, if included, during in-class time create fun time and motivates students and increases their critical thinking ability. Pre-recorded video lessons encourage the students to prepare for the class session and other pre-learning activities engage students before the class, active learning cooperative strategies employed during class time makes learning meaningful, fun and less boring, and Higher order thinking skills sustain student motivation after the class sessions and engage students outside the class time and involve actively in their learning.

The results shows that there is a significant difference in post-test in Academic Achievement in Chemistry of Experimental and Control group of students, further the mean value of 28.21 (Experimental group) is more than the mean value of 23.33 (Control group) indicates Flipped learning has increased Academic Achievement of Experimental group students, hence teachers should design educational resources and activities to engage students to prepare for their classroom activities in a better way.

The results shows that there is a significant difference in Pre-test and Post-test on Academic Achievement in Chemistry of Experimental group of students, further the mean value of 28.21 (Post-test) is greater than the mean value of 8.92 (Pretest) indicating Pre-learning resources and Active learning strategies used for teaching has greater influence on Academic Achievement in Chemistry of the students, thus teacher should assess pre-learning interactive activities provided to the students before the class and create suitable engaging activities for synchronous session.

The results shows that there is significant difference in Progressive test 1 of experimental and Control group of students, further the mean value of 20.83 (Experimental group) is greater than the mean value of 16.00 (Control group) and there is a significant difference in Progressive test 2 of experimental and Control group of students, further the mean value of 21.21 (Experimental group) is greater than the mean value of 15.12 (Control group) indicating Learning progress for experimental group of students is more than the control group of students. Hence school Heads and Principals should encourage their teachers to create and use digital classroom using LMS to provide the digital learning resources and activities for their students, and to engage the learners during in-class time actively in small groups involving active learning strategies, also they should provide opportunity for teachers to create digital worksheets so that the pre-learning and Post-learning assessment be carried out. Also motivate their teachers to participate in workshops in which they can learn to create digital interactive and engaging activities for their students to flip their classroom.

The results of 2 way- ANOVA shows that there is no significant Main effect of Sex and significant Interaction effect of Sex and Teaching Method on Academic Achievement in Chemistry, also there is no significant Main effect of levels of Socio Economic Status and significant Interaction effect of Levels of Socio Economic Status and Teaching Method on Academic Achievement in Chemistry, the teaching method has a significant Main effect on Academic Achievement in Chemistry. Hence, teachers should plan the learning activities so that they spend more time during in-class for studentstudent and student-teacher interaction to cater for all students while conducting small group activities. Heads and Principals should encourage their students to spend their time and effort in learning during pre-class and post-class at their pace and to involve in collaborative work among students to engage during in-class sessions so that students are accountable for their learning.

\section{CONCLUSION}

Flipped Learning Instructional Pedagogy engages students before, during and after the learning process, provides opportunities for teachers to flip their Chemistry class into more active and engaging. Teachers can provide more time for practical work during class session and create interest in science among their students. Flipped instructions attempts to develop interest in science, creativity, observation and experimentation skills, logical reasoning and providing practical evidences for the scientific facts and increase academic achievement.

\section{REFERENCES:}

1. Acar, B., \& Tarhan, L. (2008). Effects of cooperative learning on students' understanding of metallic bonding. Research in Science Education, 38(4), 401-420. https://doi.org/10.1007/s11165-007-9054-9

2. Alamri, M. M. (2019). Students' academic achievement performance and satisfaction in a flipped classroom in Saudi Arabia. International Journal of Technology Enhanced Learning, 11(1), 103-119. https://doi.org/10.1504/IJTEL.2019.096786

3. Bueno-Alastuey, C., \& Galar, I. A. (2017). Flipping the EFL classroom in a secondary education setting: Students' perceptions and academic performance. Huarte de San Juan. Filología y Didáctica de La Lengua, 17, 35-57.

4. Calderara, S. J., \& Wiebe, E. (2019). Activating Learning and Motivation in Undergraduate general Chemistry by Flipping the Classroom: A Mixed Methods Study. In Thesis submitted to The graduate Faculty of North Carolina State University.

5. Carlson, K. A., \& Winquist, J. R. (2011). Evaluating an active learning approach to teaching introductory statistics: A classroom workbook approach. Journal of Statistics Education, 19(1), 1-23. https://doi.org/10.1080/10691898.2011.11889596

6. "COVID-19 Impact on Education Sector: Measure and Strategies, Morocco as a case Study". International Research Journal on Advanced Science Hub, 2, 6, 2020, 21-25. doi: 10.47392/irjash.2020.32

7. Baiju Thomas. "The Role of Teachers in Facilitating 21st Century Learning Skills for Development of Creative Insight among Learners in Inclusive Classroom Settings". International Research Journal on Advanced Science Hub, 3, Special Issue ICOST 2S, 2021, 6-11. doi: 10.47392/irjash.2021.032

8. Crouch, C. H., \& Mazur, E. (2001). Peer Instruction: Ten years of experience and results. American Journal of Physics, 69(9), 970-977. 


\title{
International Advanced Research Journal in Science, Engineering and Technology
}

\author{
Vol. 8, Issue 8, August 2021
}

\section{DOI: 10.17148/IARJSET.2021.8840}

9. Estes, M. D., Ingram, R., \& Liu, J. C. (2015). A Review of Flipped Classroom Research Practice and Technologies. The Higher Education Teaching and Learning Portal, 2015 Utah, 1-10. Retrieved from https://www.hetl.org/a-review-of-flipped-classroom-research-practice-andtechnologies/

10. Glynn, J. J. (2013). The effects of a flipped classroom on achievement and student attitudes in secondary chemistry. These Submitted to Montana State University, (July), 1-56. Retrieved from http://scholarworks.montana.edu/xmlui/bitstream/1/2882/1/GlynnJ0813.pdf

11. Houseknecht, J. B. (2014). A Year of Organic Chemistry Group Work with iPads. ACS CHED CCCE Spring 2014 ConfChem: Flipped Classroom, 85(1), 2071-2079. https://doi.org/10.1016/j.bbapap.2013.06.007

12. Kaur, Gurpreet, (2018). Effect of Flipped Classroom model and Problem Solving strategies onAchivemnt and Student Engagement in Mathematics in relation to Critical Thinking. Thesis submitted to Punjab University, India. http:hdl.handle.net/10603/235168

13. Kurushkin, M., \& Mikhaylenko, M. (2016). Orbital Battleship: A Guessing Game to Reinforce Atomic Structure. Journal of Chemical Education, 93(9), 1595-1598. https://doi.org/10.1021/acs.jchemed.6b00136

14. Li, Y. Bin, Zheng, W. Z., \& Yang, F. (2017). Cooperation learning of flip teaching style on the MBA mathematics education efficiency. Eurasia Journal of Mathematics, Science and Technology Education, 13(10), 6963-6972. https://doi.org/10.12973/ejmste/76878

15. Özüdoğru, M., \& Aksu, M. (2020). Pre-service teachers' achievement and perceptions of the classroom environment in flipped learning and traditional instruction classes. Australasian Journal of Educational Technology, 36(4), 27-43. https://doi.org/10.14742/AJET.5115

16. Saad ALRowais, A. (2014). The Impact of Flipped Learning on Achievement and Attitudes In Higher Education. International Journal for CrossDisciplinary Subjects in Education, 4(Special 1), 1914-1921. https://doi.org/10.20533/ijcdse.2042.6364.2014.0266

17. Santa Montoya, C. A. (2014). Didactic strategy for the teaching of chemical equilibrium using "The Flipped Classroom" methodology and the Moodle platform. Thesis Submitted to Universidad Nacional De Colombia, 140. Retrieved from http://www.bdigital.unal.edu.co/12940/1/98658752.2014.pdf

18. Tosun, C. (2014). The Impact of MOODLE-Supported Cooperative Learning Process on University Students ' Anxiety Levels towards Chemistry Laboratory and on Their Attitudes towards Chemistry. Eurasian Journal of Physics and Chemistry Education, 6(2), 123-141.

19. Valdez, A. V., Lomoljo, A., Dumrang, S. P., \& Didatar, M. M. (2015). Developing Critical Thinking through Activity -Based and Cooperative Learning Approach in Teaching High School Chemistry. International Journal of Social Science and Humanity, 5(1), 139-141. https://doi.org/10.7763/ijssh.2015.v5.440

20. Vimala, A., \& Muniandy, P. (2018). Effectiveness of Flipped Classroom on Students' Achievement and Attitudes towards English Language in Secondary School. Journal of Innovative Technologies in Education, 2, 9-15. https://doi.org/10.1017/CBO9781107415324.0 